\title{
Effect of acclimation temperature on temperature responses of Porphyra leucosticta and Enteromorpha linza from the Gulf of Thessaloniki, Greece
}

\author{
S. Orfanidis* \& S. Haritonidis \\ Botanical Institute, Department of Biology, University of Thessaloniki; \\ 54006 Thessaloniki, Greece
}

\begin{abstract}
The effect of the acclimation temperature on the temperature tolerance of Porphyra leucosticta, and on the temperature requirements for growth and survival of Enteromorpha linza was determined under laboratory conditions. Thalli of $P$. leucosticta (blade or Conchocelis phases), acclimated to twenty-five degrees, survived up to $30^{\circ} \mathrm{C}$, i.e. $2^{\circ} \mathrm{C}$ more than those acclimated to $15^{\circ} \mathrm{C}$ which survived up to $28^{\circ} \mathrm{C}$. Lower temperature tolerance of both Porphyra phases that were acclimated to $15^{\circ} \mathrm{C}$ was $-1{ }^{\circ} \mathrm{C}$ after an 8 -week exposure time at the experimental temperatures. The upper temperature tolerance of $E$. linza also increased by $2^{\circ} \mathrm{C}$, i.e. from 31 to $33^{\circ} \mathrm{C}$, when it was acclimated to $30^{\circ} \mathrm{C}$ instead of $15^{\circ} \mathrm{C}$. The lower temperature tolerance increased from 1 to $-1{ }^{\circ} \mathrm{C}$, when it was acclimated to $5^{\circ} \mathrm{C}$ instead of $15^{\circ} \mathrm{C}$. E. linza thalli acclimated for 4 weeks to 5 or $10^{\circ} \mathrm{C}$ reached their maximum growth at $15^{\circ} \mathrm{C}$, i.e. at a $5^{\circ} \mathrm{C}$ lower temperature than those acclimated to 15 or $30^{\circ} \mathrm{C}$. These thalli achieved higher growth rates in percent of maximal growth at low temperatures than those acclimated to 15 or $30^{\circ} \mathrm{C}$. Thalli acclimated for 1 week to $5^{\circ} \mathrm{C}$ reached their maximum growth rate at $20^{\circ} \mathrm{C}$ and achieved growth rates at low temperatures similar to those recorded for thalli acclimated to $15^{\circ} \mathrm{C}$. Thalli of $E$. linza acclimated for 4 weeks to $5^{\circ} \mathrm{C}$ lost this acclimation after being post-cultivated for the same period at $15^{\circ} \mathrm{C}$. That was not the case with thalli acclimated for 8 weeks to $5^{\circ} \mathrm{C}$ and post-acclimated for 4 weeks to $15^{\circ} \mathrm{C}$. These thalli displayed similar growth patterns at $10-25^{\circ} \mathrm{C}$, while a decline of growth rate was observed at 5 or $30^{\circ} \mathrm{C}$. The significance of the acclimation potential of $E$. linza with regard to its seasonality in the Gulf of Thessaloniki, and its distribution in the $\mathrm{N}$ Atlantic, is also discussed.
\end{abstract}

\section{INTRODUCTION}

Seasonal changes of temperature and photoperiod in natural environments may have forced seaweeds to develop different strategies for survival. Among those strategies (Lüning, 1990), temperature responses to seasonal acclimation (sensu Berry \& Björkman, 1980) may be related to perennial seaweeds or seaweeds with an isomorphic life cycle. For instance, Laminaria spp. shifted their upper survival limit from winter to summer by up to $5^{\circ} \mathrm{C}$ (Lüning, 1984). Far greater, seasonal changes have been demonstrated in the frost tolerance of macroalgae (Gessner, 1970; Lüning, 1990). The effect of temperature acclimation on photosynthetic responses of algae was recently reviewed by Davison

\footnotetext{
- Present address of first author: Centre for Marine Biology, University of Groningen, Biological Centre, P.O. Box 14, 9750 AA Haren (Gn), The Netherlands
}

(c) Biologische Anstalt Helgoland, Hamburg 
(1991), while more extensive reviews of the same effect on higher plants are those by Berry \& Björkman (1980) and Berry \& Raison (1981).

Lampe (1935) showed a different acclimation potential of photosynthetic rates between eurythermal (e.g. Fucus serratus) or stenothermal (e.g. Porphyra hiemalis) species. A number of studies from marine invertebrates (reviews by Precht et al., 1973; Kinne, 1970) indicated that acclimation (or non-genetic adaptation in the terminology of Precht et al., 1973; Kinne, 1970) need not appear in all species, and is more often in eurythermal than in stenothermal ones. Several macroalgae change their temperature growth requirements (Egan et al., 1989; Orfanidis, 1990, 1993; Bischoff \& Wiencke, 1993) and temperature tolerance (Schwenke, 1959; Feldmann \& Lutova, 1963; Yarish et al., 1984) in response to acclimation temperature, but others do not (Yarish et al., 1987). Thus, the question raised by Yarish et al. (1987) about the ability of macroalgae to change their temperature responses in response to acclimation temperature still exists.

Temperature responses determined under laboratory conditions have been used in ecological biogeography over the last decades (Breeman, 1988; Lüning, 1990). In most cases, the tested seaweed was acclimated at a medium temperature, depending on its climatic affinity, either before being transferred directly to experimental conditions (Orfanidis, 1991; tom Dieck, 1993) or after a short acclimation procedure had taken place (Peters \& Breeman, 1992; Bischoff \& Wiencke 1993). In all cases, the significance of acclimation conditions was noted and in the case of ecotypic variation within a species it was extensively discussed (Breeman, 1988; Novaczek et al., 1989) However, less attention was paid to the possible importance of acclimation, for the explanation of limits of macroalgae (Orfanidis, 1993).

One objective of this study was to investigate the ability of Porphyra leucosticta or Enteromorpha linza from Thessaloniki, Greece to change their survival limits and/or the temperature requirements for growth. A second objective was to evaluate the significance of acclimation for seasonality and distribution of $E$. linza in the Gulf of Thessaloniki and in the N Atlantic Ocean.

\section{MATERIALS AND METHODS}

Unialgal cultures of Porphyra leucosticta and Enteromorpha linza were established from plants collected near Thessaloniki, Greece (Thermaikos Gulf; $40.38^{\circ} \mathrm{N}, 22.58^{\circ} \mathrm{E}$ ) in February and April 1986. They were transported in an insulated cooling container to a laboratory of the Biologische Anstalt Helgoland in Hamburg. Unialgal cultures were propagated at $15 \pm 2{ }^{\circ} \mathrm{C}$ in 2- or 3-1 glass-beakers filled with von Stosch's enriched seawater (VSES; modified after Guiry \& Cunningham, 1984) and aerated with membrane-filtered air for at least two years before the experiments were started. A photon fluence rate of $20-40 \mu \mathrm{mol} \mathrm{m} \mathrm{m}^{-2} \mathrm{~s}^{-1}$ was provided at $16 \mathrm{~h}$ light per day by cool-white fluorescent tubes (Osram L $40 \mathrm{~W} / 25 \mathrm{~S}$ ). Cultivation methods and equipment used in this study were described in detail by Orfanidis (1991).

Temperature tolerance experiments were performed by incubating differently acclimated individuals at high $\left(27-36^{\circ} \mathrm{C}\right)$ or low $\left[(-1)-4^{\circ} \mathrm{C}\right]$ temperatures. Temperaturecontrolled water baths (Haake D8-V water bath-cryostat units; Haake, Karlsruhe, Germany) were used for temperatures $\geqslant 0^{\circ} \mathrm{C}$ (all $\pm 0.1^{\circ} \mathrm{C}$ ) and a constant-temperature room for $-1{ }^{\circ} \mathrm{C}\left( \pm 0.5^{\circ} \mathrm{C}\right)$. Standard light conditions were cool-white fluorescent light, a photon 
fluence rate of $30 \mu \mathrm{mol} \mathrm{m} \mathrm{m}^{-2} \mathrm{~s}^{-1}$ and $12 \mathrm{~h}$ light per day. After the treatments, individuals tested for lower temperature tolerance were post-cultivated at $15 \pm 2{ }^{\circ} \mathrm{C}$ and those tested for upper temperature tolerance at $20 \pm 1{ }^{\circ} \mathrm{C}\left(20 \mu \mathrm{mol}\right.$ photons $\mathrm{m}^{-2} \mathrm{~s}^{-1}, 16 \mathrm{~h}$ light per day $)$. Four weeks later, the viability of the plants was investigated visually and microscopically to determine whether plants had either survived and exhibited normal coloration, or regenerated from injured thallus, or were dead. In cases where there was any doubt about the viability of the test material, the post-cultivation was prolonged for another 4 weeks.

Growth experiments for $E$. linza were performed in temperature-controlled water baths (Haake D8-V, Karlsruhe, Germany; $\pm 0.2^{\circ} \mathrm{C}$ ) at $5,10,15,20,25$ and $30^{\circ} \mathrm{C}$. The photon fluence rate at the surface of the water baths was $60-80 \mu \mathrm{mol} \mathrm{m}^{-2} \mathrm{~s}^{-1}$ (Osram L 65 $\mathrm{W} / 25 \mathrm{~S}$ and Osram L $40 \mathrm{~W} / 25 \mathrm{~S}$ ). The day length was $16 \mathrm{~h}$ light per day. The growth of $E$. linza was determined as increase of fresh weight after a 1 -week experimental period at each temperature in material which was acclimated at $5,10,15$ and $30^{\circ} \mathrm{C}$. Growth was calculated as follows:

$$
\text { Relative growth rate }(\mathrm{RGR})=\left(\ln \mathrm{N}_{\mathrm{t}}-\ln \mathrm{N}_{\mathrm{o}}\right) / \mathrm{t} \times 7\left(\text { week }^{-1}\right)
$$

$\left[N_{0}=\right.$ fresh weight; $N_{t}=$ fresh weight after $t$ days; $t=$ experimental time (days) $]$

\section{RESULTS}

\section{Effect of acclimation temperature on lower and upper temperature tolerance}

The blade or Conchocelis phases of Porphyra leucosticta acclimated for at least two years to $15^{\circ} \mathrm{C}$ survived for 8 weeks at $-1^{\circ} \mathrm{C}$. The upper temperature tolerance of the blade phase of $P$. leucosticta as a function of exposure time is shown in Table 1.

Table 1. Upper temperature tolerance of the blade phase of Porphyra leucosticta. Plants were acclimated for at least 2 years to $15^{\circ} \mathrm{C}$ or for 12 weeks to $25^{\circ} \mathrm{C}$ (results in brackets). Results evaluated after 4 or 8 weeks postcultivation at $20^{\circ} \mathrm{C}, 20 \mu \mathrm{mol}$ photons $\mathrm{m}^{-2} \mathrm{~s}^{-1}, 16 \mathrm{~h}$ light per day; + : plants alive or regenerated from injured thallus; - : plants dead

\begin{tabular}{|c|c|c|c|c|c|c|}
\hline \multirow{2}{*}{$\begin{array}{l}\text { Time } \\
\text { (days) }\end{array}$} & \multicolumn{6}{|c|}{ Experimental temperatures $\left({ }^{\circ} \mathrm{C}\right)$} \\
\hline & 27 & 28 & 29 & 30 & 31 & 32 \\
\hline 1 & $+(+)$ & $+(+)$ & $+(+)$ & $+1+1$ & $-(+)$ & $-(+)$ \\
\hline 2 & $+(+1$ & $+(+)$ & $+(+)$ & $-i+1$ & $-(+)$ & $-(+)$ \\
\hline 3 & $+(+)$ & $+(+)$ & $+(+)$ & $-i+1$ & $-(+)$ & $-(+)$ \\
\hline 4 & $+(+)$ & $+(+)$ & $+i+1$ & $-i+1$ & $-(+)$ & $-(-)$ \\
\hline 5 & $+(+)$ & $+(+)$ & $+(+)$ & $-(+)$ & $-(+)$ & $-(-)$ \\
\hline 6 & $+(+)$ & $+(+)$ & $+1+1$ & $-1+1$ & $-(+)$ & $-(-)$ \\
\hline 7 & $+1+1$ & $+(+)$ & $+1+1$ & $-1+1$ & $-(+)$ & $-i-)$ \\
\hline 10 & $+(+)$ & $+(+)$ & $-(+)$ & $-(+)$ & $-(+)$ & $-(-)$ \\
\hline 14 & $+(+)$ & $+1+1$ & $-1+1$ & $-(+)$ & $-(-)$ & $-(-)$ \\
\hline 21 & $+(+)$ & $+i+1$ & $-(+)$ & $-1+1$ & $-(-)$ & $-(-)$ \\
\hline 28 & $+(+)$ & $+(+)$ & $-(+)$ & $-(+)$ & $-(-)$ & $-(-)$ \\
\hline 35 & $+(+)$ & $+(+)$ & $-(+)$ & $-(+)$ & $-(-)$ & $-(-)$ \\
\hline 42 & $+(+)$ & $+(+)$ & $-i+1$ & $-i+1$ & $-(-)$ & $-(-)$ \\
\hline
\end{tabular}


Table 2. Upper temperature tolerance of the Conchocelis phase of Porphyra leucosticta. Plants were acclimated for at least 2 years to $15^{\circ} \mathrm{C}$ or for 8 weeks to $25^{\circ} \mathrm{C}$ (results in brackets). nt $=$ not tested (see Table 1 for further details)

\begin{tabular}{|ccccccc|}
\hline $\begin{array}{l}\text { Time } \\
\text { (days) }\end{array}$ & 27 & 28 & 29 & 30 & 31 & 32 \\
\hline 14 & $+(+)$ & $+(+)$ & $-(+)$ & $-(+)$ & $-(+)$ & $\mathrm{nt}(-)$ \\
28 & $\mathrm{nt}(+)$ & $\mathrm{nt}(+)$ & $\mathrm{nt}(+)$ & $\mathrm{nt}(+)$ & $\mathrm{nt}(+)$ & $\mathrm{nt}(-)$ \\
56 & $\mathrm{nt}(+)$ & $\mathrm{nt}(+)$ & $\mathrm{nt}(+)$ & $\mathrm{nt}(+)$ & $\mathrm{nt}(-)$ & $\mathrm{nt}(-)$ \\
\hline
\end{tabular}

Table 3. Lower temperature tolerance of Enteromorpha linza. Plants were acclimated for at least 2 years to $15^{\circ} \mathrm{C}$ or for 8 weeks to $5^{\circ} \mathrm{C}$ (results in brackets). Results evaluated after 4- or 8-week postcultivation at $15^{\circ} \mathrm{C}, 20 \mu \mathrm{mol}$ photons $\mathrm{m}^{-2} \mathrm{~s}^{-1}, 16 \mathrm{~h}$ light per day; + : plants alive; $\mathrm{R}$ : regeneration from injured thallus; - : plants dead

\begin{tabular}{|ccccccc|}
\hline $\begin{array}{l}\text { Time } \\
\text { (days) }\end{array}$ & -1 & 0 & 1 & 2 & 3 & 4 \\
\hline & $+(+)$ & $+(+)$ & $+(+)$ & $+(+)$ & $+(+)$ & $+(\mathrm{nt})$ \\
1 & $+(+)$ & $+(+)$ & $+(+)$ & $+(+)$ & $+(+)$ & $+(\mathrm{nt})$ \\
7 & $+(+)$ & $+(+)$ & $+(+)$ & $+(+)$ & $+(+)$ & $+(\mathrm{nt})$ \\
14 & $\mathrm{R}(+)$ & $\mathrm{R}(+)$ & $+(+)$ & $+(+)$ & $+(+)$ & $+(\mathrm{nt})$ \\
28 & $\mathrm{R}(+)$ & $\mathrm{R}(+)$ & $\mathrm{R}(+)$ & $+(+)$ & $+(+)$ & $+(\mathrm{nt})$ \\
42 & $-(\mathrm{R})$ & $-(+)$ & $\mathrm{R}(+)$ & $+(+)$ & $+(+)$ & $+(\mathrm{nt})$ \\
56 & $-(\mathrm{R})$ & $-(+)$ & $\mathrm{R}(+)$ & $+(+)$ & $+(+)$ & $+(\mathrm{nt})$ \\
\hline
\end{tabular}

Table 4. Upper temperature tolerance of Enteromorpha linza. Plants acclimated for at least 2 years to $15^{\circ} \mathrm{C}$ and for 8 weeks to $30^{\circ} \mathrm{C}$ (results in brackets). Results evaluated after 4- or 8-week postcultivation at $20^{\circ} \mathrm{C}, 20 \mu \mathrm{mol}$ photons $\mathrm{m}^{-2} \mathrm{~s}^{-1}, 16 \mathrm{~h}$ light per day, (see Table 3 for explanation of symbols)

\begin{tabular}{|cccccccc|}
\hline $\begin{array}{c}\text { Time } \\
\text { (days) }\end{array}$ & 30 & 31 & 32 & 33 & 34 & 35 & 36 \\
\hline 1 & $+(+)$ & $+(+)$ & $+(+)$ & $+(+)$ & $\mathrm{R}(+)$ & $\mathrm{R}(+)$ & $-(+)$ \\
3 & $+(+)$ & $+(+)$ & $+(+)$ & $+(+)$ & $-(+)$ & $-(+)$ & $-(\mathrm{R})$ \\
7 & $+(+)$ & $+(+)$ & $+(+)$ & $\mathrm{R}(+)$ & $-(+)$ & $-(\mathrm{R})$ & $-(-)$ \\
14 & $+(+)$ & $+(+)$ & $\mathrm{R}(+)$ & $-(+)$ & $-(\mathrm{R})$ & $-(-)$ & $-(-)$ \\
28 & $+(+)$ & $+(+)$ & $\mathrm{R}(+)$ & $-(+)$ & $-(\mathrm{R})$ & $-(-)$ & $-(-)$ \\
42 & $+(+)$ & $+(+)$ & $-(\mathrm{R})$ & $-(\mathrm{R})$ & $-(-)$ & $-(-)$ & $-(-)$ \\
56 & $+(+)$ & $+(+)$ & $-(\mathrm{R})$ & $-(\mathrm{R})$ & $-(-)$ & $-(-)$ & $-(-)$ \\
\hline
\end{tabular}




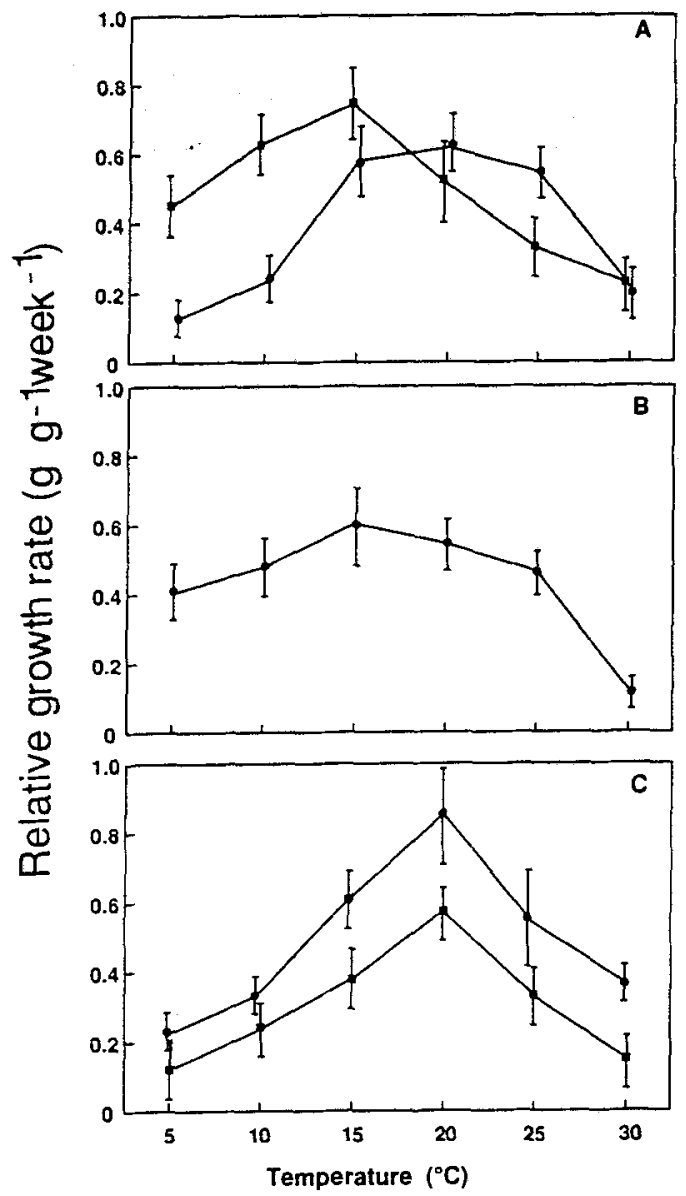

Fig. 1. Mean relative growth rates (RGR) of Enteromorpha linza (n $=6-8$ ), measured at $5^{\circ} \mathrm{C}$ temperature intervals (vertical bars $=95 \%$ confidence intervals). Standard light conditions: $60-80$ $\mu \mathrm{mol}$ photons $\mathrm{m}^{-2} \mathrm{~s}^{-1}, 16 \mathrm{~h}$ light per day. A: Individuals acclimated for 1 week $(\bullet)$ or 4 weeks $(\boldsymbol{m})$ to $5^{\circ} \mathrm{C}$. B: Individuals acclimated for 4 weeks to $10^{\circ} \mathrm{C}(\bullet)$. C: Individuals acclimated for at least 2 years to $15^{\circ} \mathrm{C}(\bullet)$ or for 4 weeks to $30^{\circ} \mathrm{C}$ (a)

Individuals of the blade phase acclimated for at least two years to $15^{\circ} \mathrm{C}$ survived up to $28^{\circ} \mathrm{C}$ after 42 days exposure time, while individuals acclimated for 12 weeks to $25^{\circ} \mathrm{C}$ survived up to $30^{\circ} \mathrm{C}$ after the same exposure time. The upper temperature tolerance of the Conchocelis phase of $P$. leucosticta as a function of exposure time is shown in Table 2. Individuals of the Conchocelis phase acclimated for at least two years to $15^{\circ} \mathrm{C}$ survived up to $28^{\circ} \mathrm{C}$ after 14 days exposure time, while individuals acclimated for two months to $25^{\circ} \mathrm{C}$ survived up to $30^{\circ} \mathrm{C}$ after 56 days exposure time.

The lower temperature tolerance of Enteromorpha linza as a function of exposure time is shown in Table 3 . The lower survival temperature of individuals acclimated for at 
least two years to $15^{\circ} \mathrm{C}$ was $1^{\circ} \mathrm{C}$ after 56 days exposure time, while the lower survival temperature of individuals acclimated for 8 weeks to $5^{\circ} \mathrm{C}$ was $-1{ }^{\circ} \mathrm{C}$ after the same exposure time. The upper temperature tolerance of $E$. linza as a function of exposure time is shown in Table 4 . Individuals acclimated for at least two years to $15^{\circ} \mathrm{C}$ survived up to $31{ }^{\circ} \mathrm{C}$ after 56 days exposure time, while individuals acclimated for 8 weeks to $30^{\circ} \mathrm{C}$ survived up to $33^{\circ} \mathrm{C}$ after the same exposure time.

\section{Effect of acclimation temperature on temperature growth requirements}

Thalli of Enteromorpha linza acclimated for 4 weeks to 5 or $10^{\circ} \mathrm{C}$ reached their growth maximum at $15^{\circ} \mathrm{C}$. Thalli acclimated for 1 week to $5^{\circ} \mathrm{C}$ for 4 weeks to $30^{\circ} \mathrm{C}$, or for at least two years to $15^{\circ} \mathrm{C}$, reached their growth maximum at $20^{\circ} \mathrm{C}$ (Fig. 1). Individuals acclimated for 4 weeks to lower temperatures $\left(5\right.$ or $\left.10^{\circ} \mathrm{C}\right)$ grew better to $5(62-68 \%$ of maximum growth rate) or $10^{\circ} \mathrm{C}(80-85 \%$ of maximum growth rate) than did individuals acclimated to higher temperatures $\left(15\right.$ or $30^{\circ} \mathrm{C}$ ). Individuals acclimated to 15 or $30^{\circ} \mathrm{C}$ exhibited at 5 or $10^{\circ} \mathrm{C} 25-27 \%$ or $39-44 \%$ of their maximum growth rate, respectively. Thalli acclimated for 1 week to $5^{\circ} \mathrm{C}$ achieved similar percentage growth rates of the maximum value at $5(20 \%)$ or $10^{\circ} \mathrm{C}(38 \%)$ as those acclimated to $15^{\circ} \mathrm{C}$ (Fig. 1). Growth rates of individuals acclimated for 4 weeks to 5 or $30^{\circ} \mathrm{C}$ or for at least two years to $15^{\circ} \mathrm{C}$, declined linearly at temperatures of $20-30^{\circ} \mathrm{C}$, whereas individuals acclimated for 1 week to $5^{\circ} \mathrm{C}$ or for 4 weeks to $10^{\circ} \mathrm{C}$ grew quite well at $25^{\circ} \mathrm{C}$ ( 88 and $77 \%$ of maximum growth rate, respectively) (Fig. 1).

Individuals that were acclimated for 4 weeks to $5^{\circ} \mathrm{C}$ and then were transferred for 4 weeks to $15^{\circ} \mathrm{C}$ grew at a similar rate as those grown at $15^{\circ} \mathrm{C}$. Individuals that were acclimated for 8 weeks to $5^{\circ} \mathrm{C}$ and then were transferred for 4 weeks to $15^{\circ} \mathrm{C}$ grew similarly at temperatures of $10-25^{\circ} \mathrm{C}$ ( $>80 \%$ of maximum growth rate), while growth rate declined at 5 and $30^{\circ} \mathrm{C}$ ( 34 and $55 \%$ of maximum growth rate, respectively) (Fig. 2).

\section{DISCUSSION}

Although the temperature tolerance of a species is genetically determined (Gessner, 1970; Larcher, 1983; Lüning, 1984, 1990), it can gradually change with exposure time to a constant value (Levitt, 1980; Larcher \& Bauer, 1981). Upper temperature tolerance of the blade phase of Porphyra leucosticta decreased by $2^{\circ} \mathrm{C}$ after $10-14$ incubation days and stayed fixed afterwards (Table 1). The upper temperature tolerance of Polyneura hilliae also became stable after an exposure time of 14 days (Yarish et al., 1987). The upper tolerance limit of Enteromorpha linza did not stabilize until after an exposure time of 6 weeks (Table 4), and in the filamentous gametophytes of Laminaria the upper tolerance limit still changed after 8 weeks of incubation (tom Dieck, 1993).

As far as low temperature tolerance is concerned, an exposure time of 6 weeks was sufficiently long for stabilizing the lower temperature tolerance of $E$. linza (Table 3 ). The lower survival limit for Choristocarpus tenellus became constant after an incubation time of 5 weeks (Orfanidis, 1991), while Colpomenia peregrina and Gigartina teedii reached their constant lower survival limit after an incubation time of 6 or 8 weeks (Orfanidis, 1993). 


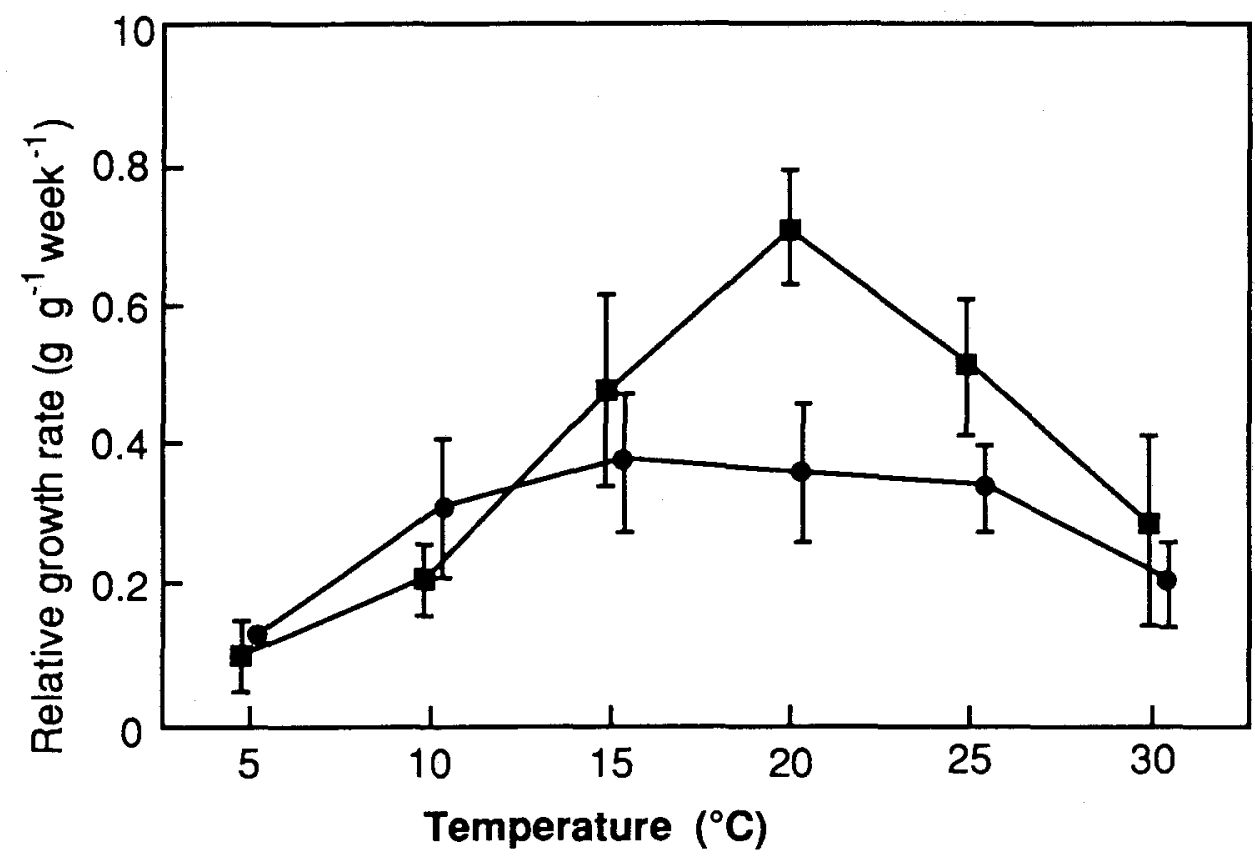

Fig. 2. Mean relative growth rates of Enteromorpha linza $(\mathrm{n}=6-8)$. Individuals acclimated for 4 weeks to $5^{\circ} \mathrm{C}$ and post-acclimated for 4 weeks to $15^{\circ} \mathrm{C}$. Individuals acclimated for 8 weeks to $5^{\circ} \mathrm{C}$ and post-acclimated for 4 weeks to $15^{\circ} \mathrm{C}$ (see legend of Fig. 1 for further details)

Acclimation to different temperatures may influence the temperature tolerance of a species only in a genetically determined restricted interval (Precht et al., 1973; Kappen, 1981; Steponkus, 1981). E. linza thalli acclimated for 8 weeks to temperatures near to their lower or upper survival limits, exceeded the 'normal' tolerance limits by $2{ }^{\circ} \mathrm{C}$, compared to values determined for experimental algae acclimated to a medium temperature $\left(15^{\circ} \mathrm{C}\right.$ ) (Tables 3,4$) . P$. leucosticta thalli acclimated to $25^{\circ} \mathrm{C}$ also survived $2^{\circ} \mathrm{C}$ more than did thalli acclimated to $15^{\circ} \mathrm{C}$ (Tables 1,2). Yarish et al. (1987) acclimated nine species for one month in two temperatures differing by $10^{\circ} \mathrm{C}$, but in all cases the survival limits obtained were identical. Yarish et al. (1984) also reported that the tropical species Solieria tenera survived for 42 days at $0{ }^{\circ} \mathrm{C}$, after being acclimated gradually for 2 weeks to 10 and $5^{\circ} \mathrm{C}$.

Ecologically, the temperature tolerance acclimation of E. linza and P. leucosticta is probably of no importance in their native habitats. As the surface seawater temperature in the Gulf of Thessaloniki ranges between 7 to $27^{\circ} \mathrm{C}$ (Fig. 3), both species could easily survive without an acclimation potential.

Differences in temperature tolerance according to seasonal changes has often been demonstrated. Laminaria spp. and Desmarestia aculeata from Helgoland shifted their upper tolerance limit from winter to summer by $2-5^{\circ} \mathrm{C}$ (Lüning, 1984). The existence of a seasonal change in cold tolerance was reported for other algae (review by Gessner, 1970; Lüning, 1990). Feldmann \& Lutova (1963) observed that the heat and cold tolerance of the 


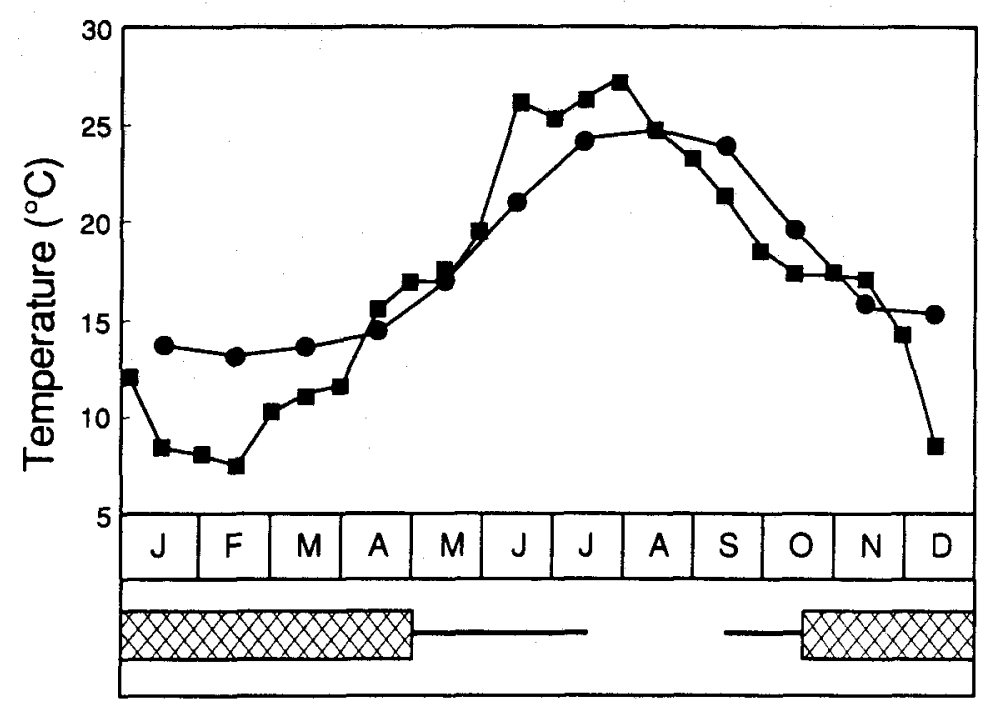

Fig. 3. Surface seawater temperatures in the Gulf of Thessaloniki. • Monthly mean measurements for 20 years (1952-1972); - monthly measurements for 1971. Seasonal occurrence of the population of Enteromorpha linza in the Gulf of Thessaloniki: - presence; $\mathbb{K}$ growth optimum (after Haritonidis, 1978)

brown algae Fucus spp. and Ascophyllum nodosum rises and falls in summer, while the opposite occurs in winter. Although these shifts in survival limits were regarded as an acclimation to seasonal changes in temperature, some recent evidence indicates that the lower survival temperature of an alga may increase with decreased day length (Cambridge et al., 1984, 1987, 1990, Yarish et al., 1984, 1986).

Sporophytes of Laminaria longicruris acclimated for 4 weeks to $5^{\circ} \mathrm{C}$ reached their growth maximum at $10-15^{\circ} \mathrm{C}$, while those acclimated to $15^{\circ} \mathrm{C}$ grew maximally at $5^{\circ} \mathrm{C}$ (Egan et al., 1989). Five or $10^{\circ} \mathrm{C}$-acclimated thalli of $E$. linza reached their growth maximum at $15^{\circ} \mathrm{C}$, i.e. at a $5^{\circ} \mathrm{C}$ lower temperature than in the case of 15 - or $30^{\circ} \mathrm{C}$ acclimated thalli (Fig. 1). No shift of the growth optimum was observed in Scytosiphon lomentaria and Gigartina teedii, irrespective of acclimation temperature (Orfanidis, 1990). Germlings of Scytosiphon lomentaria acclimated to $15^{\circ} \mathrm{C}$ grew and developed into macrothalli at $5-27^{\circ} \mathrm{C}$; while thalli acclimated to $5^{\circ} \mathrm{C}$ did the same at $5-25^{\circ} \mathrm{C}$. Thalli of Gigartina teedii acclimated to $15^{\circ} \mathrm{C}$ grew better at low temperatures than did thalli acclimated to 5 or $30^{\circ} \mathrm{C}$ (Orfanidis, 1993).

$E$. linza grows almost all the year round in the Gulf of Thessaloniki, with maximum rates in winter and spring (Fig. 3). Based on the temperature requirements for growth of $15^{\circ} \mathrm{C}$-acclimated thalli (maximum at $20^{\circ} \mathrm{C}$ ) E. linza may be considered as a "warmadapted plant". However, the growth vs. temperature curve shifted to lower temperatures, with acclimation to low temperatures. Plants acclimated to 5 or $10^{\circ} \mathrm{C}$ achieved higher growth rates in percentage of maximum growth at low temperatures than those acclimated to 15 or $30^{\circ} \mathrm{C}$ (Fig. 1). This potential for growth acclimation probably allows Enteromorpha to optimize its growth under limiting temperature conditions in winter and to act as a "cold-adapted plant" during this period. 
The stabilization phase (Kinne, 1970) of growth acclimation of E. linza continued for more than 1 week. Individuals acclimated for 1 week to $5^{\circ} \mathrm{C}$ achieved similar growth rates at low temperatures as $15^{\circ} \mathrm{C}$-acclimated individuals, when comparing the growth rates in percentage of maximum growth (Fig. 1). After 4 weeks of acclimation to $5^{\circ} \mathrm{C}$, the growth rates of $E$. linza at $5^{\circ} \mathrm{C}$ increased three times more, and at $10^{\circ} \mathrm{C}$ twice more than the growth rates of $15^{\circ} \mathrm{C}$-acclimated individuals, again when compared as percentage of maximum growth rate. An increase of growth rates within the first 2 weeks of acclimation at 0 or $5^{\circ} \mathrm{C}$ and a following stabilization of growth rates during the next 3 weeks was also reported for Acrosiphonia sonderi (Bischoff \& Wiencke, 1993).

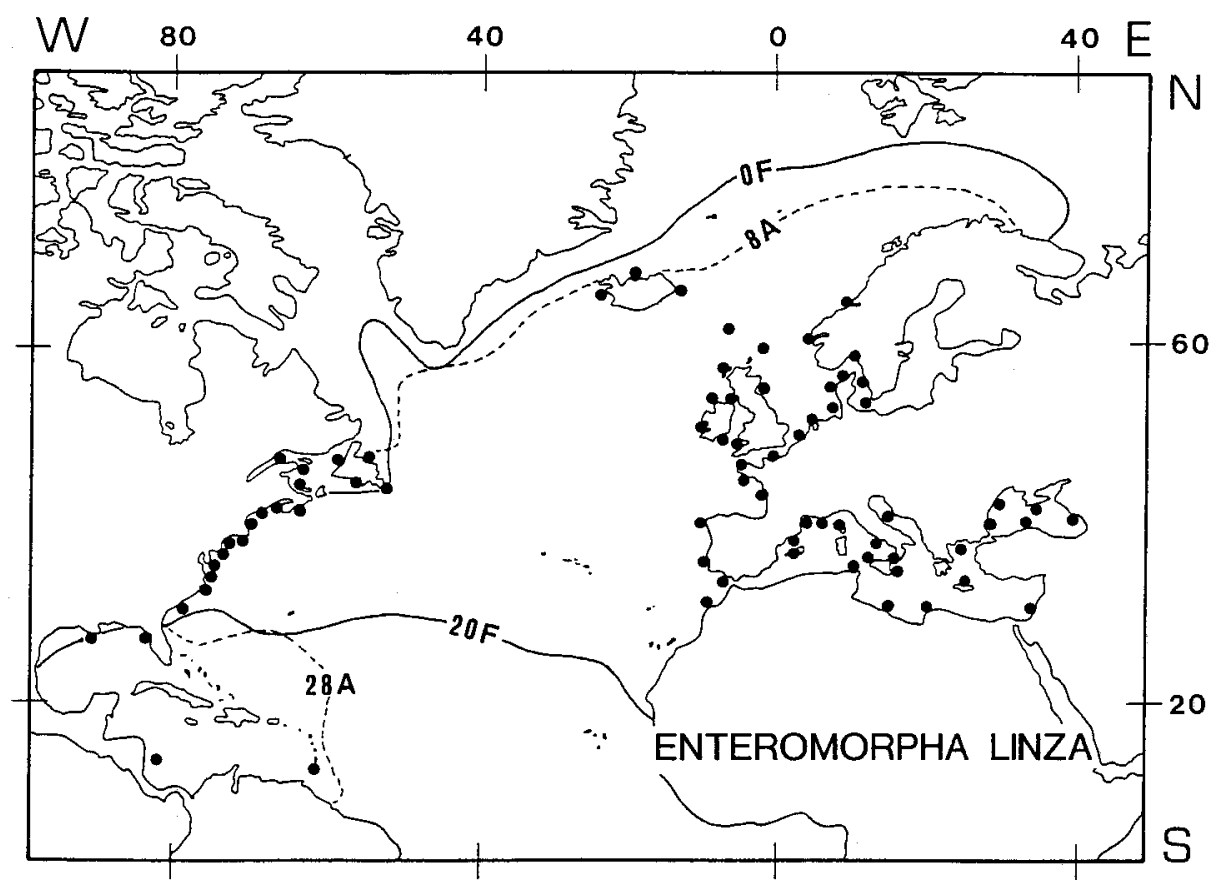

Fig. 4. Distribution of Enteromorpha linza in the North Atlantic Ocean. Map shows the geographic distribution and the ocean isotherms for February $(F)$ and August $(A)$ at the distribution boundaries. The oceanic isotherms were adopted from Gorskov World Ocean Atlas (1985). Sources: N Atlantic (South \& Tittley, 1986), NE Atlantic (Børgesen \& Jonsson, 1905), Iceland (Munda, 1977, 1983, 1985, 1987), Norway (Prinz, 1926; Sundene, 1953; Jorde, 1966), Sweden (Levring, 1935), Denmark (Christensen et al., 1985), Helgoland (Kornmann \& Sahling, 1977), Netherlands (Stegenga \& Mol, 1983), Belgium (Coppejans \& Ben van der, 1980), British Isles (Blackler, 1956; Guiry, 1978; Norton \& Powell, 1979; Wilkinson, 1982), N France (Feldmann, 1954; Gayral \& Bert, 1965), W France (Lancelot, 1961; Bouxin \& Dizerbo, 1971), NW Spain (Perez-Cirera, 1975), Portugal (Ardré, 1970), SW Spain (Seoane-Camba, 1965), Mediterranean (Furnari, 1984), Baleares (Ribera \& Gómez, 1985), S France (Belsher et al., 1976), Corsica (Boudouresque \& Perret, 1977), Tunesia (Meñez \& Mathieson, 1981), Libya (Nizamuddin et al., 1978), Israel (Lipkin \& Safriel, 1971), Aegean Sea (Athanasiadis; 1987), Black Sea (Zinova, 1967). Morocco (Gayral, 1958), tropical W Africa (Lawson \& Price, 1969), E Canada (Cardinal, 1967), N Carolina (Searles \& Schneider, 1978), W Florida (Dawes, 1974), Lesser Antilles (Taylor, 1969), Colombia (Schnetter, 1978) 
Biogeographically, the northern distribution limit of $E$. linza on the North Atlantic coast (Fig. 4) suggests a northern growth and/or reproduction boundary at the $8^{\circ} \mathrm{C}$ August isotherm, which corresponds to a minimum mean summer temperature of $6^{\circ} \mathrm{C}$ permitting growth and/or reproduction. The experimental data (Fig. 1, Table 3) show that the northern boundary may not represent a growth boundary, but could be considered as a reproduction boundary at the $8^{\circ} \mathrm{C}$-August isotherm, despite the absence of reproduction data. The growth acclimation potential of $E$. linza at low temperatures may provide better growth at its northern distribution boundary; it occurs from April to September at Helgoland (Kornmann \& Sahling, 1977) and is a summer-fall annual in Iceland (Munda, $1977,1983,1985,1987$ ) and in Newfoundland (South \& Hooper, 1980). The ability of $E$. linza to cope with temperatures of 0 or $-1{ }^{\circ} \mathrm{C}$ (Table 3) after being acclimated to $5^{\circ} \mathrm{C}$ explains its distribution along the eastern coasts of $\mathrm{N}$ America up to Newfoundland and in those regions of Europe, e.g. North Sea and Black Sea, in which extreme winter temperatures approach $0^{\circ} \mathrm{C}$ (Fig. 4). Due to the upper survival temperature limit at $31^{\circ} \mathrm{C}$ and the temperature requirements for growth of $15^{\circ} \mathrm{C}$-acclimated plants, the southern distribution boundary of $E$. linza on the western coasts of the N Atlantic Ocean is a lethal boundary at the $28^{\circ} \mathrm{C}$-August isotherm. The temperature tolerance acclimation potential may favour the existence of this species in regions with water temperatures rising to more than $30^{\circ} \mathrm{C}$, e.g. at brackish-water habitats in warm temperate regions of $\mathrm{N}$ America (Lüning, 1990). The southern distribution limit of E. linza on the European/African coasts cannot be explained according to the experimental data (Fig. 1, Table 4). This species could be expected to penetrate further south along the western coasts of Africa.

Acknowledgements. This work was supported by the German Academic Exchange Service (DAAD) and is based on a Ph. D. study in the Department of Biology, University of Thessaloniki. We are very grateful to Prof. Dr. K. Lüning for advice, for his hospitality and working facilities during the stay of S. O. in his laboratory. We thank Dr. I. tom Dieck and anonymous referees for constructive comments on the manuscript. Thanks are also due to Prof. Dr. Tsekos for helping as a member of the Ph. D. advisory committee.

\section{LITERATURE CITED}

Ardré, F., 1970. Contribution à l'étude des algues marines du Portugal. I. La flore. - Port. Acta biol. $10 \mathrm{~B}, 137-555$.

Athanasiadis, A., 1987. A survey of the seaweeds of the Aegean Sea with taxonomic studies on species of the tribe Antithamnieae (Rhodophyta). Thesis, Goterna, Kungälv, $174 \mathrm{pp}$.

Belsher, T., Augier, H., Boudouresque, C.-F. \& Coppejans, E., 1976. Inventaire des algues marines benthiques de la rade et des îles d'Hyères (Méditerranée France). - Trav. scient. Parc natn. PortCros 2, 39-89.

Berry, J. A. \& Björkman, O., 1980. Photosynthetic response and adaptation to temperature in higher plants. - A. Rev. Pl. Physiol. 31, 491-543.

Berry, J.A. \& Raison, J. K., 1981. Responses of macrophytes to temperature. In: Encyclopedia of plant physiology. Ed. by O. L. Lange, P. S. Nobel, C. B. Osmond \& H. Ziegler. Springer, Berlin, 12 A, $277-338$.

Bischoff, B. \& Wiencke, C., 1993. Temperature requirements for growth and survival of macroalgae from Disko Island (Greenland). - Helgoländer Meeresunters. 47, 167-191.

Blackler, H., 1956. The phenology of certain algae at St. Andrews, Fife. - Trans. Proc. bot. Soc. Edinb. 37 (1), 60-78.

Borgesen, F. \& Jonsson, H., 1905. The distribution of the marine algae of the Arctic and of the northernmost of the Atlantic. - Botany Faeröes 3, Appendix 1-28. 
Boudouresque, C.F. \& Perret, N., 1977. Inventaire de la flore marine de Corse (Méditerranée): Rhodophyceae, Phaeophyceae, Chlorophyceae et Bryopsidophyceae. - Bibithca phycol. 25. $1-170$.

Bouxin, H. \& Dizerbo, A. H., 1971. Les algues de l'Archipel des Glenan. - Botanica Rhedonica (A) 10, 201-226.

Breeman, A. M., 1988. Relative importance of temperature and other factors in determining geographic boundaries of seaweeds: experimental and phenological evidence. - Helgoländer Meeresunters. 42, 199-241.

Cambridge, M. L., Breeman, A. M. \& Hoek, C. van den, 1990. Temperature responses limiting the geographical distribution of two temperate species of Cladophora (Cladophorales: Chlorophyta) in the North Atlantic Ocean. - Phycologia 29, 74-85.

Cambridge, M. L., Breeman, A. M., Kraak, S. \& Hoek, C. van den, 1987. Temperature responses of tropical to warm temperate Cladophora species in relation to their distribution in the North Atlantic Ocean. - Helgoländer Meeresunters. 41, 329-354.

Cambridge, M. L., Breeman, A. M., Oosterwijk, R. van \& Hoek, C. van den, 1984. Temperature responses of some North Atlantic Cladophora species (Chlorophyceae) in relation to their geographic distribution. - Helgoländer Meeresunters. 38, 349-363.

Cardinal, A., 1967. Inventaire des algues marines benthiques de la Baie des Chaleurs et de la Baie de Caspe (Quebec). I. Phéophycées. II. Chlorophycées. III. Rhodophycées. - Naturaliste can. 94, 233-271, 447-469, 735-760.

Christensen, T., Koch, C. \& Thomsen, H. A., 1985. Distribution of algae in Danish salt and brackish waters. Institut for Sporeplanter, Copenhagen, $64 \mathrm{pp}$.

Coppejans, E. \& Ben, D. van der, 1980. Zeewierengids voor de Belgische en Noordfranse kust. Belgische Jeugdbond voor Natuurstudie, Gent, $156 \mathrm{pp}$.

Davison, I. R., 1991. Environmental effects on algal photosynthesis: temperature. - J. Phycol. 27, 2-8.

Dawes, C. J., 1974. Marine algae of the west coast of Florida. Univ. of Miami Press, Coral Gabies, $201 \mathrm{pp}$.

Dieck, I. tom, 1993. Temperature tolerance and survival in darkness of kelp gametophytes (Laminariales, Phaeophyta): ecological and biogeographical implications. - Mar. Ecol. Prog. Ser. $100,253-264$

Egan, B., Vlasto, A. \& Yarish, C., 1989. Seasonal acclimation to temperature and light in Laminaria longicruris de la Pyl. (Phaeophyta). - J. exp. mar. Biol. Ecol. 129, 1-16.

Feldmann, J., 1954. Inventaire de la flore marine de Roscoff. - Trav. Stn biol. Roscoff 6 (Suppl.) $1-152$.

Feldmann, N. L. \& Lutova, M.I., 1963. Variations de la thermostabilité cellulaire des algues en fonctions des changements de la température du milieu. - Cah. Biol. mar. 4, 435-458.

Furnari, G., 1984. The benthic marine algae of southern Italy. - Webbia 38, 349-369.

Gayral, P., 1958. Algues de la côte Atlantique Marocaine. Société des sciences naturelles et physiques du Maroc, Rabat, $523 \mathrm{pp}$.

Gayral, P.\& Bert, J. J., 1965. Compte rendu de l'excursion de la société phycologique de France en Normandie. - Bull. Soc. linn. Normandie (Ser. 10) 6, 122-129.

Gessner, F., 1970. Temperature: plants. In: Marine ecology. Ed. by O. Kinne. Wiley, New York, 1 (1), $363-406$.

Gorshkov, S. G. (Ed.), 1985. World Ocean Atlas. 2: Atlantic and Indian oceans. Pergamon Press, Oxford, $306 \mathrm{pp}$.

Guiry, M.D., 1978. A consensus and bibliography of Irish seaweeds. Cramer, Vaduz, $287 \mathrm{pp}$.

Guiry, M.D. \& Cunningham, E.M., 1984. Photoperiodic and temperature responses in the reproduction of north-eastern Atlantic Gigartina acicularis (Rhodophyta: Gigartinales). - Phycologia 23, 357-367.

Haritonidis, S., 1978. A survey of the marine algae of Thermaikos Gulf, Thessaioniki, Greece. I. Distribution and seasonal periodicity. - Botanica mar. 21, 527-535.

Jorde, I., 1966. Algal associations of a coastal area south of Bergen, Norway. - Sarsia 23, 1-52.

Kappen, L., 1981. Ecological significance of resistance to high temperature. In: Encyclopedia of plant physiology. Ed. by O. L. Lange, P.S. Nobel, C. B. Osmond \& H. Ziegler. Springer, Berlin, 12 A. $439-474$. 
Kinne, O., 1970. Temperature: invertebrates. In: Marine ecology. Ed. by O. Kinne. Wiley, New York, $1(1), 407-514$.

Kornmann, P. \& Sahling P.-H., 1977. Meeresalgen von Helgoland. Benthische Grün-, Braun- und Rotalgen. - Helgoländer wiss. Meeresunters. 29, 1-289.

Lampe, H. 1935. Die Temperatureinstellung des Stoffgewinns bei Meeresalgen als plasmatische Anpassung. - Protoplasma 23, 534-578.

Lancelot, A., 1961. Recherches biologiques et océanographiques sur les végétaux marins des côtes francaises entre la Loire et la Gironde. Muséum National d'Histoire de Cryptogamie, Paris, 210 pp.

Larcher, W., 1983. Physiological plant ecology. Springer, Berlin, $303 \mathrm{pp}$.

Larcher, W. \& Bauer, H., 1981. Ecological significance of resistance to low temperature. In: Encyclopedia of plant physiology. Ed. by O. L. Lange, P.S. Nobel, C. B. Osmond \& H. Ziegler. Springer, Berlin, 12 A, 403-437.

Lawson, G.W. \& Price, J.H., 1969. Seaweeds of the western coast of tropical Africa and adjacent islands: a critical assessment. I. Chlorophyta and Xanthophyta. - J. Linn. Soc. (Botany) 62, 279-346.

Levitt, J., 1980. Responses of plants to environmental stresses. Acad. Press. New York, 1, 1-497.

Levring, T., 1935. Zur Kenntnis der Algenflora von Kullen an der schwedischen Westküste. - Lunds Univ. Årsskr. (N. F. 2) 31 (4), 1-64.

Lipkin, Y. \& Safriel, U., 1971. Intertidal zonation on rocky shores at Mikhmoret (Mediterranean, Israel). - J. Ecol. 59, 1-30.

Lüning, K., 1984. Temperature tolerance and biogeography of seaweeds: the marine algal flora of Helgoland (North Sea) as an example. - Helgoländer Meeresunters. 38, 305-317.

Lüning, K., 1990. Seaweed biogeography and ecophysiology. Wiley, New York. 527 pp.

Meñez, E. G. \& Mathieson, A. C., 1981. The marine algae of Tunesia. - Smithson. Contr. mar. Sci. 10, $1-59$.

Munda, I. M., 1977. The benthic algal vegetation of the island of Grimsey (Eyjafjaroarsýsla, North Iceland). - Bull. Res. Inst. Nedri Ás 28, 1-69.

Munda, I. M., 1983. Survey of the benthic algal vegetation of the Reydarfjordur as a typical example of the East Icelandic vegetation pattern. - Nova Hedwigia 37, 545-640.

Munda, I.M., 1985. General survey of the benthic algal vegetation along the Baroastrond coast (Breioafjorour, West Iceland). - Bull. Res. Inst. Nedri Ás 44, 1-62.

Munda, I. M., 1987. Characteristic features of the benthic algal vegetation along the Snaefellsnes peninsula (southwest Iceland). - Nova Hedwigia 44, 399-448.

Nizamuddin, M., West, J. A. \& Meñez, E. G., 1978. A list of marine algae from Libya. - Botanica mar. $22,465-476$.

Norton, T. A. \& Powell, H. T., 1979. Seaweeds and rocky shores of the Outer Hebrides. - Proc. R. Soc. Edinb. 77 B, 141-153.

Novaczeck, I., Breeman, A.M. \& Hoek, C. van den, 1989. Thermal tolerance of Stypocaulon scoparium (Phaeophyta, Sphacelariales) from eastern and western shores of the North Atlantic Ocean. - Helgoländer Meeresunters. 43, 183-193.

Orfanidis, S., 1990. Temperature and photoperiodic responses of several Mediterranean macroalgae in relation to their distribution in the North Atlantic Ocean. Thesis, Univ. of Thessaloniki, $171 \mathrm{pp}$.

Orfanidis, S., 1991. Temperature responses and distribution of macroalgae belonging to the warmtemperate Mediterranean Atlantic distribution group. - Botanica mar. 34, 541-552.

Orfanidis, S., 1993. Temperature responses and distribution of several Mediterranean macroalgae belonging to different distribution groups. - Botanica mar. 36, 359-370.

Perez-Cirera, J. L., 1975. Catalógo floristico de las algas bentonicas de la Ria de Corme y Lage, NO. de España. - Anal. Inst. bot. A. J. Cavanillo 32, 5-87.

Peters, A.F. \& Breeman, A.M., 1992. Temperature responses of disjunct temperate brown algae indicate long-distance dispersal of microthalli across the tropics. - J. Phycol. 28, 428-438.

Precht, H., Christophersen, J., Hensel, H. \& Larcher, W. (Eds), 1973. Temperature and life. Springer, Berlin, $779 \mathrm{pp}$.

Prinz, H., 1926. Die Algenvegetation des Trondhjemsfjordes. - Skr. norske VidenskAkad. (Mat.naturv. KI.) $5,1-274$. 
Ribera Siguàn, M. A. \& Gómez Carreta, A., 1985. Checklist of the benthic marine flora of the Balearic Islands. II. Phaeophyceae, Chlorophyceae. - Collnea bot. 16 (1), 25-41.

Schnetter, R., 1978. Marine Algen der Karibischen Küste von Kolumbien. II. Chlorophyceae. Biblthca phycol. 42, 1-198.

Schwenke, H., 1959. Untersuchungen zur Temperaturresistenz mariner Algen der westlichen Ostsee. I: Das Resistenzverhalten von Tiefenrotalgen bei ökologischen und nicht-ökologischen Temperaturen. - Kieler Meeresforsch. 15, 34-50.

Searles, R. B. \& Schneider, C. W., 1978. A checklist and bibliography of North Carolina seaweeds. Botanica mar. 21, 99-108.

Seoane-Camba, J. A., 1965. Estudios sobre las algas bentonicas en la costa sur de la Peninsula Ibérica (litoral de Cadiz). - Investigación pesq. 29, 3-216.

South, G. R. \& Hooper, R. G., 1980. A catalogue and atlas of the benthic marine algae of the island of Newfoundland. - Occ. Pap. Biol. Meml Univ. Newfoundl. 3, 1-136.

South, G. R. \& Tittley, I., 1986. A checklist and distributional index of the benthic marine algae of the North Atlantic Ocean. British Museum (Natural History), London, $76 \mathrm{pp}$

Stegenga, H. \& Mol, I., 1983. Flora van de Nederlandse Zeewieren. Koninklijke Nederlandse Natuurhistorische Vereniging, Amsterdam, $263 \mathrm{pp}$.

Steponkus, P. L., 1981. Responses to extreme temperatures. Cellular and subcellular bases. In: Encyclopedia of plant physiology. Ed. by O. L. Lange, P.S. Nobel, C. B. Osmond \& H. Ziegler. Springer, Berlin, 12 A, 371-402.

Sundene, O., 1953. The algal vegetation of the Oslofjord. - Skr. norske VidenskAkad. (Mat.-naturv. Kl.) $2,1-244$.

Taylor, W. R., 1969. Notes on the distribution of West Indian marine algae particularly in the Lesser Antilles. - Contr. Univ. Mich. Herb. 9, 125-203.

Yarish, C., Breeman, A. M. \& Hoek, C. van den, 1984. Temperature, light and photoperiod responses of some Northeast American and West European endemic rhodophytes in relation to their geographic distribution. - Helgoländer Meeresunters. 38, 273-304.

Yarish, C., Breeman, A. M. \& Hoek, C. van den, 1986. Survival strategies and temperature responses of seaweeds belonging to different distribution groups. - Botanica mar. 29, 215-230.

Yarish, C., Kirkman, H. \& Lüning, K., 1987. Lethal exposure times and preconditioning to upper temperature limits of some temperate North Atlantic red algae. - Helgoländer Meeresunters. 41, 323-327.

Wilkinson, M., 1982. Marine algae from Glamorgan. - Br. phycol. J. 17, 101-106.

Zinova, A. D., 1967. Identification of green, brown and red algae in the Southern Seas of U.S.S.R. Izdatel'stvo Akademii Nauka, Moskva, 398 pp. (In Russian). 